2 Sladek K, Dworski R, FitzGerald GA, et al. Allergen-stimulated release of thromboxane $A_{2}$ and leukotriene $\mathrm{E}_{4}$ in humans. Am Rev Respir Dis 1990; 141: $1441-5$.

\section{Recruiting patients to clinical trials: lessons from studies of growth hormone treatment in renal failure}

EDITOR,-We were interested in Professor Campbell's commentary on our recent paper.' Many of the important points he raises such as entry criteria, trial design, and patient selection were dealt with in the accompanying paper. ${ }^{2}$ It would have been helpful if we had made it clear that these two papers were companion papers by including more cross references. Neither report makes it clear that the studies had ethical committee approval and as Professor Campbell raises this point we can confirm that the protocols for both studies had been submitted separately to our local ethics committee and received its approval.

We disagree that 'some recruitment bias must have been introduced by the rather complex process of obtaining "staged" informed consent'. Our experience was the reverse. Inevitably it does take time to discuss such complicated issues adequately but the process does not need to be very complex: about $50 \%$ of our families required only a single interview. Thirty of 31 eligible patients took part in the psychological study and 28 of 31 eligible patients opted for treatment with growth hormone. Thus it was possible to involve families in the decision without biasing recruitment whilst protecting against families accepting uncritically prior decisions of the professionals.

$$
\begin{array}{r}
\text { R J POSTLETHWATTE } \\
\text { J M REYNOLDS } \\
\text { A JWOOD } \\
\text { D M EMINSON } \\
\text { Royal Manchester Children's Hospital, } \\
\text { Hospital Road, } \\
\text { Pendlebury, } \\
\text { Manchester M27 4HA }
\end{array}
$$

1 Postlethwaite RJ, Reynolds JM, Wood AJ, Evans JHC, Lewis MA, Eminson DM. Recruitin patients to clinical trials: lessons from studies of growth hormone treatment in renal failure. Arch Dis Child 1995; 73: 30-5.

2 Reynolds JM, Wood AJ, Eminson DM, Postlethwaite RJ. Short stature and chronic parents? Arch Dis Child 1995; 73: 36-42.

Osteogenesis imperfecta, non-accidental injury, and temporary brittle bone disease

EDITOR,-The commentary which followed the paper by Smith prompts me to comment. ${ }^{1}$ The most widely used classification of osteogenesis imperfecta is that of Sillence. ${ }^{2}$ Type IVA is the type most likely to be confused with inflicted injury. At the time of the first fracture the skeleton may be normal and there are no stigmata of osteogenesis imperfecta.

Metaphyseal injuries are regarded as specific of inflicted injury in infancy. ${ }^{3}$ However, Paterson in a study of type IVA osteogenesis imperfecta noted that metaphyseal fractures do occur. ${ }^{4}$ The validity of his work has been both vigorously criticised ${ }^{5}$ and defended ${ }^{6}$ and remains controversial.

In the commentaries Hobbs and Wynne and Carty state that the metaphyseal fractures of osteogenesis imperfecta do not cause diagnostic confusion as the skeleton will always indicate obvious bone disease. In making that assertion they refer to the work of Astley. ${ }^{\text {? }}$ Their argument is specious. Astley's paper was received by the journal in 1978. The type IVA variant was first described by Sillence in 1979. It is therefore not surprising that Astley concluded 'in all of these there was generalised bone disease so that confusion with non-accidental injury did not occur'

RAN BLUMENTHAL
Roydham Hospital, Royal Oldham Hospital,
Rochdale Road, Rochdale Road,
Oldham OL1 2 fH

1 Smith R. Osteogenesis imperfecta, non-accidental injury, and temporary brittle bone disease. Arch Dis Child 1995; 72: 169-76.

2 Sillence DO, Senn A, Danks DM. Genetic het erogeneity in osteogenesis imperfecta. $\mathcal{F} \mathrm{Med}$ Genet 1979; 16: 101-16.

3 Blumenthal I. Child abuse. $A$ handbook for health care practitioners. London: Edward Arnold, 1994: 75-7.

4 Paterson C, Mc Allison S, Shaw J. Clinical and radiological features of osteogenesis imperfecta type IVA. Acta Paediatr Scand 1987; 76: 548-52.

5 Ablin DS, Greenspan A, Reinhart M, Grix A Differentiation of child abuse from osteogenesis imperfecta. AfR 1990; 154: 1035-46.

6 Paterson CR, Mc Allison SJ. Differentiation of child abuse from osteogenesis imperfecta $A \mathscr{f} R$ 1990; 155: 1346-7.

7 Astley R. Metaphyseal fractures in osteogenesis imperfecta. Br F Radiol 1979; 52: 441-3. 